\title{
Modelo de cuantificación del consumo energético en edificación
}

\section{Quantification model for energy consumption in edification}

\author{
Ma. P. Mercader ${ }^{(*)}$, M. Olivares ${ }^{(*)}$, A. Ramírez de Arellano(*)
}

Recepción/Received: 2-V-11

Aceptación/Accepted: 15-VII-12

\section{RESUMEN}

La investigación realizada en el presente trabajo plantea la generación de un modelo de cuantificación del consumo energético en edificación, a través de uno de los indicadores de impacto ambiental más relevantes asociados al peso por $\mathrm{m}^{2}$ de construcción, el consumo energético derivado del proceso de fabricación de los materiales de construcción empleados en edificación.

La aplicación práctica del modelo propuesto sobre diferentes tipologías edificatorias en Sevilla aportará información respecto a los materiales de construcción, subsistemas y elementos constructivos más impactantes, permitiendo visualizar la influencia que presenta la superficie construida en cuanto al impacto ambiental generado.

Los resultados obtenidos pretenden servir de referencia a la comunidad científica, aportando datos numéricos que podrán ser comparados en otras tipologías y ámbitos geográficos, a la vez que permitirán analizar y precisar mejoras en cuanto al impacto ambiental generado por los diferentes materiales, subsistemas y elementos constructivos habitualmente utilizados en las tipologías edificatorias definidas.

Palabras clave: acero, árido, hormigón, madera, cerámica, yeso.

\section{SUMMARY}

The research conducted in this paper focuses on the generation of a model for the quantification of energy consumption in building. This is to be done through one of the most relevant environmental impact indicators associated with weight per $\mathrm{m}^{2}$ of construction, as well as the energy consumption resulting from the manufacturing process of materials used in building construction.

The practical application of the proposed model on different buildings typologies in Seville, will provide information regarding the building materials, the subsystems and the most relevant construction elements. Hence, we will be able to observe the impact the built surface has on the environment.

The results obtained aim to reference the scientific community, providing quantitative data comparable to other types of buildings and geographical areas. Furthermore, it may also allow the analysis and the characterization of feasible solutions to reduce the environmental impact generated by the different materials, subsystems and construction elements commonly used in the different building types defined in this study.

Keywords: steel, agregates, concrete, wod, ceramic, gypsum.
(*) Universidad de Sevilla (Sevilla, España).

Persona de contacto/Corresponding author: pmm@us.es 


\section{INTRODUCCIÓN}

La actividad generada por el sector de la construcción, incluida su industria asociada, es la mayor consumidora de recursos naturales. A nivel mundial, las obras civiles y la construcción de edificios consumen el $60 \%$ de las materias primas extraídas de la litosfera. De este volumen, la construcción representa el $40 \%$ (1). En la Unión Europea, la construcción de edificios consume el $40 \%$ de los materiales, las extracciones de minerales per cápita ascienden a 4,8 toneladas por habitante y año (2), consume el $40 \%$ de la energía primaria y genera el $40 \%$ de los residuos, teniendo especial responsabilidad en el actual deterioro del medio ambiente la ampliación del parque construido (3).

En España los resultados son similares, la construcción y uso de edificios, en el contexto total de impactos de la sociedad, supone un $32 \%$ en cuanto al consumo de energía no renovable, un $30 \%$ de la generación de emisiones de $\mathrm{CO}_{2}$, de efecto invernadero, un $24 \%$ de las extracciones de materiales de la corteza terrestre, que junto al $17 \%$ del agua potable consumida hacen un total de $41 \%$ del consumo de recursos naturales y finalmente suponen entre el $30-40 \%$ de los residuos sólidos generados (4).

Estudios realizados por el Instituto para la Diversificación y el Ahorro de la energía (IDAE) nos muestran que cerca de una tercera parte de la energía precisada en nuestro país está ligada directamente a la edificación, por un lado, la consumida en la fabricación de los materiales con los que construimos nuestros edificios y, por otro, para mantener las condiciones de habitabilidad derivadas del uso que albergan. En España, la cantidad de energía invertida en la fabricación de determinados materiales por metro cuadrado, considerando la superficie de suelo en un edificio estándar, es igual a la cantidad de energía producida en la combustión de más de 150 I de petróleo (5). Este metro cuadrado construido conlleva una emisión media de $0,5 \mathrm{t}$ de $\mathrm{CO}_{2}$ y un consumo energético de $5.754 \mathrm{MJ}(1)$.

La incidencia de las emisiones de $\mathrm{CO}_{2}$ en la industria de la construcción también es muy notable y está vinculada al consumo energético, la Directiva 2002/91/CE del Parlamento Europeo y del Consejo de 16 de diciembre de 2002 las considera un indicador de la eficiencia energética de los edificios en el sector residencial y terciario; ya que esta tasa puede ser medida y cuantificada, en términos energéticos y en términos de emisiones de $\mathrm{CO}_{2}$. Algunos autores como Goldenberg calculan que un tercio del consumo energético y, por lo tanto, de la producción de este gas viene directamente 0 indirectamente de la actividad de la construcción (6). Otros, como Webb (7) o Edwards and Hyett (8), precisan que cerca del $50 \%$ del

\section{INTRODUCTION}

The activity generated by the construction industry, including its associated industry, is the largest consumer of natural resources. Globally, civil works and buildings construction consumes $60 \%$ of raw materials extracted from the lithosphere. Of this amount, construction accounts for $40 \%$ (1). In the European Union, the construction of buildings consumes $40 \%$ of materials and $40 \%$ of primary energy, as well as it generates $40 \%$ of waste. Mineral extractions per capita rise to 4.8 tons per capita-year (2) and the expansion of the built park had a particular responsibility in the current environmental degradation (3).

Results are similar in Spain. The construction and the use of buildings, in the overall context of society impacts, represent $32 \%$ of the non-renewable energy consumption, $30 \%$ of the generation of $\mathrm{CO}_{2}$ emissions and $24 \%$ of the materials extraction from the Earth's crust. What's more, taking in conjunction with the $17 \%$ of drinking water consumed, the construction and the use of buildings mean $41 \%$ of natural resources consumption, and finally amount about $30-40 \%$ of the solid waste generated (4).

Studies conducted by the Institute for Energy Diversification and Energy Saving show that about one third of the needed energy in our country is directly tied to building. On one hand, it is consumed in the manufacture of materials employed to construct our buildings. On the other hand, it is used to maintain living conditions resulting from their usage. In Spain, the amount of energy expended in the manufacture of certain materials per $\mathrm{m}^{2}$-taking into consideration the soil surface in a standard building - is the same to the sum of energy produced by the combustion of more than 150 litres of oil (5). This leads to a square meter average emission of 0.5 tonnes of $\mathrm{CO}_{2}$ and an energy consumption of $5754 \mathrm{MJ}$ (1).

The impact of $\mathrm{CO}_{2}$ emissions in the construction industry is also very remarkable and it is linked to the energy consumption. The Directive 2002/91/EC of the European Parliament and the Council of the $16^{\text {th }}$ December 2002 consider it as an indicator of the buildings' energetic efficiency in the residential and tertiary sector. Furthermore, it can be measured and quantified both in terms of energy and of $\mathrm{CO}_{2}$ emissions. Some authors as Goldenberg estimate a third of the energy consumption -and hence of the production of this gas- comes directly or indirectly from the construction activity (6). Others, like Webb (7) or Edwards and Hyett (8), assert that about $50 \%$ of the energy expenses in developed 
coste energético total en los países desarrollados está estrechamente vinculado o es una consecuencia de la industria de la construcción, si añadimos al resultado final los consumos requeridos para su consumo y mantenimiento, tales como calefacción, refrigeración, iluminación, etc. (9).

De los tres sectores principales en que se divide el gasto energético de un país (el consumo para el mantenimiento y climatización de edificios, el transporte y la industria) nos centraremos en la última, concretando en la industria de la construcción, al entender por un lado que las primeras están siendo ya estudiadas positivamente por instituciones y consumidores con el uso de energías alternativas y renovables y un consumo responsable. Por otro lado, los arquitectos, considerados en ocasiones gestores de recursos en el proceso constructivo deben comprometerse con el medio ambiente desde el diseño y la selección de productos de construcción que generen menos impacto ambiental y que requieran un menor consumo energético en su proceso de fabricación.

Para conocer el alcance de las modificaciones ambientales ocasionadas por la industria de la construcción, surge, entre otras, la metodología de análisis del ciclo de vida (ACV) de los materiales, de los que existen numerosos estudios publicados que utilizan el ACV para evaluar el impacto ambiental de diferentes materiales y soluciones constructivas (10), a la vez que existen diferentes enfoques y simplificaciones a tener en cuenta (11), y numerosos programas y herramientas informáticas de aplicación (12-14), entre las que citar el programa español TCQ-2000 asociado al Banco Estructurado de Elementos Constructivos (BEDEC), del Instituto de Tecnología de la Construcción de Catalunya (ITeC) (15).

En definitiva, la selección de materiales o sistemas de construcción a través de estos procesos requieren de un rigor y especialización propios de científicos, investigadores y empresas de consultoría especializadas en impacto ambiental; además no recogen los aspectos más locales de la construcción (16). Por lo tanto, el objetivo de esta investigación es desarrollar una metodología de cálculo, de fácil manejo, al servicio de cualquier agente del proceso constructivo, aplicable a cualquier tipología de edificios y ámbito geográfico, que nos permita realizar una diagnosis, mediante la cuantificación del impacto ambiental, en términos energéticos, del sector de la construcción en edificios de uso residencial, desde la óptica de los recursos materiales seleccionados y consumidos en su proceso de ejecución y la cantidad de energía consumida en su proceso de fabricación.

Se realiza su aplicación práctica a dos tipologías de edificios residenciales, consideradas como habituales en el countries is closely correlated with the construction industry (or it is a consequence of it). That if we consider the final consumption required for maintenance such as heating, cooling, lighting, and so on (9).

Of the three main sectors into which we divide the energy expenses of a country (consumption for maintenance and air conditioning in buildings, transportation and industry), we will focus on the last one, specifically in the construction industry. Firstly, because we understand institutions and consumers are studying the others in the context of alternative and renewable energy and responsible consumption. Secondly, because architects, who are sometimes considered managers of the resources in the construction process, must commit to the environment in the design and the selection of building products that generate less environmental impact and that require less energy in the process of manufacture.

The methodology of life cycle analysis (LCA) of materials is one of the used to know the scope of the environmental changes caused by the construction industry. It appears in numerous published studies that use the LCA to assess the environmental impact of different materials and construction solutions (10). At the same time, there are different approaches and simplifications to consider (11), as well as several programs and computer tools for their implementation (12-14). For instance, we can mention the Spanish program TCQ-2000, associated with the Structured Constructive Elements Bank (Banco Estructurado de Elementos Constructivos-BEDEC) and the Institute of the Technology of Construction from Catalonia (Instituto de Tecnología de la Construcción de Catalunya-ITeC) (15).

Ultimately, the selection of materials or construction systems done by these processes requires rigor and specialization of the Scientifics, researchers and consulting firms focused on the environment impact (16). Furthermore, they do not involve the local aspects of the construction. Therefore, the aim of this research is to develop a calculation methodology, easy to use, available for any agent of the construction process and applicable to any type of building or geographical area, allowing us to make a diagnosis by the quantification of the environmental impact -in energetic terms - carried by the construction sector. Specifically, it will focus in residential buildings from the perspective of selected materials and resources consumed in their process of implementation and the amount of energy consumed in their manufacturing process.

Its practical application focuses on two different residential buildings, considered usual at a national level 
ámbito nacional y que son construidas en Sevilla; edificios residenciales en altura destinados a viviendas colectiva, viviendas de protección oficial y conjuntos residenciales destinados a viviendas unifamiliares adosadas, asociadas a edificios de poca altura y desarrollo horizontal, a fin de determinar la influencia de la superficie construida en el impacto ambiental ocasionado por la construcción de los edificios que habitualmente se construyen en esta provincia, asociado al uso de la energía primaria empleada en la fabricación de los materiales de construcción comúnmente utilizados, lo que representa un indicador global transcendental; tanto por la energía requerida en estos procesos como por las cantidades de residuos tóxicos que generan.

El proceso desarrollado permitirá identificar y cuantificar tanto los materiales de construcción como los subsistemas constructivos de mayor impacto en términos energéticos, proporcionando un modelo sobre el que ensayar y comparar en investigaciones futuras propuestas de mejora que minimicen el impacto ambiental ocasionado, tanto por la elección de los materiales de construcción por otros de menor consumo energético en su proceso de fabricación, como en las propuestas de soluciones constructivas más ecoeficientes. Asimismo podrá ser comparado con investigaciones precedentes publicadas en la misma área, determinando la influencia de la zona climática en el impacto ocasionado.

\section{PARTE EXPERIMENTAL}

Para lograr la meta propuesta es necesaria la consecución de unos objetivos complementarios de rango menor, organizados en tres niveles ordenados jerárquicamente, atendiendo a su prioridad temporal en su consecución, recogidos en la Figura 1. En el Nivel 1, el objetivo es seleccionar una muestra de estudio representativa de las tipologías edificatorias consideradas más habituales en el sector de la construcción, que denominaremos Modelos Constructivos Habituales (MCHs) y and which are built in Seville: residential buildings in high for collective subsidized housing and residential complexes for terraced houses with low and horizontal development. The objective is to determine the impact of the surface constructed to the environment, caused by the construction of buildings which are usual in the region, associated with the use of primary energy employed in the manufacture of commonly used building materials. This represents a far-reaching indicator, both because of the energy required in these processes and the amounts of toxic waste they generate.

The process developed will identify and quantify both building materials and construction sub-systems with the greatest impacts in terms of energy. Therefore, it will provide a model on which to test and compare future improvement suggestions that may minimize the environmental impact, both by choices of building materials with smaller energy consumption in their manufacturing process and by proposals of more ecoefficient constructive solutions. Likewise, it may also be compared with previous researches published about the same topic, studying thus the influence of the climatic area on the impact caused.

\section{EXPERIMENTAL PART}

To achieve our aim, it is necessary to accomplish complementary goals. They are organized in three levels, ordered according to the priority in their execution, as reflected in Figure 1. At Level 1, the objective is both to select a study sample representative of the most common types of buildings considered in the construction sector -labelled as Common Constructive Model (CCM) - and quantify the building materials consumed in its construction in $\mathrm{kg}$ per $\mathrm{m}^{2}$ built -called

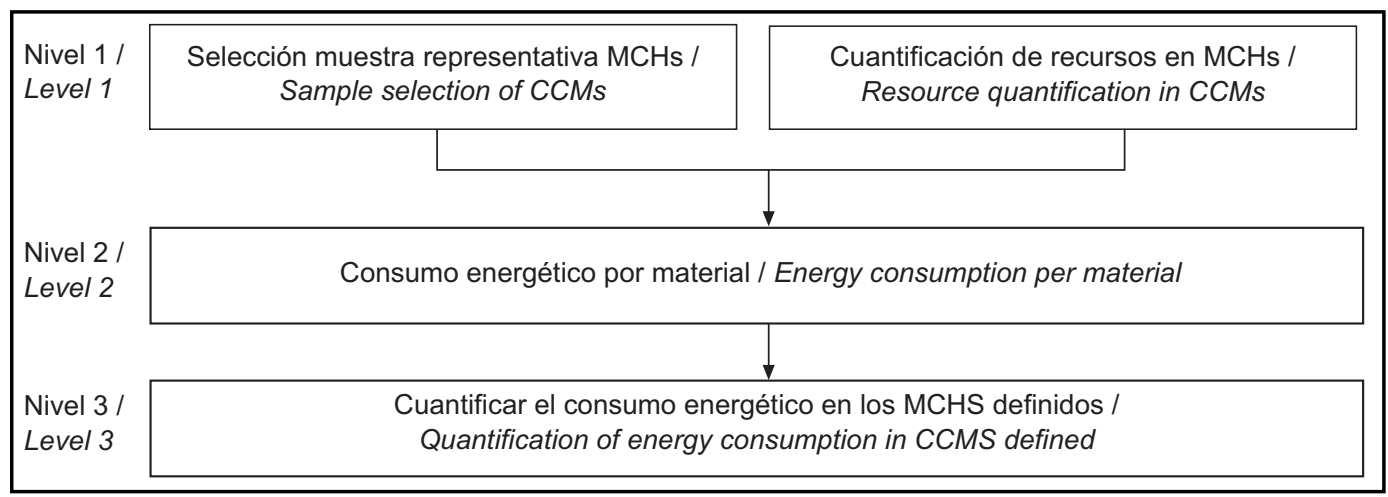

Figura 1. Jerarquía de objetivos.

Figure 1. Hierarchy of objectives. 
cuantificar en $\mathrm{kg}$ por $\mathrm{m}^{2}$ construido cada uno de los materiales de construcción consumidos en su ejecución, denominados componentes básicos materiales (CBMs). En el Nivel 2, el objetivo es conocer el consumo energético, expresado en $\mathrm{MJ} / \mathrm{kg}$, requerido en el proceso de fabricación de $1 \mathrm{~kg}$ de cada CBM implicado en la ejecución de los MCHs definidos. La consecución de los objetivos planteados en los niveles inferiores permite en el Nivel 3 cuantificar el consumo energético en la ejecución de los $\mathrm{MCHs}$, en $\mathrm{MJ} / \mathrm{m}^{2}$ de superficie construida, derivados de la fabricación de los CBMs que los constituyen.

La consecución de los objetivos planteados se lleva a cabo mediante el desarrollo de la siguiente metodología, estructurada a su vez en el mismo orden jerárquico, relacionando en sentido descendente las diferentes etapas y subetapas necesarias para lograr el objetivo principal y en sentido horizontal, las necesarias para cubrir los objetivos de rango menor planteados en cada nivel, Figura 2.

El desarrollo pormenorizado es el siguiente:

Etapa 1. Satisface el objetivo de rango menor considerado en este nivel, la selección y cuantificación de una muestra de edificios representativos de las tipologías constructivas definidas como las habituales, denominadas MCHs, suficiente en número para considerar los futuros resultados representativos. Para ello es necesario el desarrollo de las siguientes subetapas:

a. Definición de los Modelos Constructivos Habituales. Las fuentes utilizadas para su definición han sido las publicaciones estadísticas editadas por el Ministerio de Fomento en los últimos cinco años. Dado que las tipologías edificatorias más habituales coinciden tanto a nivel nacional como en Andalucía, las muestras para el estudio son tomadas del trabajo de campo realizado en el Servicio de Licencias Urbanísticas de la Gerencia de
Basic Material Component (BMC)-. At Level 2, the purpose is to determine the energy consumption expressed in $\mathrm{MJ} / \mathrm{kg}$, required in the manufacturing process of $1 \mathrm{~kg}$ of each BCM involved in the execution of the CCMs defined. Achieving the goals set at the lower levels, allow us (at level 3) to quantify the energy consumption in the implementation of the CCMs. It is measured in $\mathrm{MJ} / \mathrm{m}^{2}$ of floor area, derived from the manufacture of the BCMs that form them.

The achievement of the objectives is done by developing the following methodology (Figure 2), structured following the same scale, linking vertically the different stages and sub-stages necessary to achieve the main objective and horizontally the necessary ones to cover the goals from lower levels.

Find below the details of its development:

Step 1. It satisfies the lower range objective considered at this level: the selection and quantification of a sample of buildings from usual types of construction, called CCMs, sufficient in number to be considered representative for future results. This requires the development of the following sub-steps:

a. Defining the Common Constructive Models. The sources used for its definition have been statistical publications issued by the Ministerio de Fomento (Spanish Ministry of Promotion) in the last five years. Since the most common building types coincide in Spain and in Andalusia, samples for the study are taken from fieldworks done by the Service for Planning Permissions of the Management Planning of Seville and by municipal

\begin{tabular}{|c|c|c|c|}
\hline & Objetivos / Objectives & Metodología / Metodology & \\
\hline $\begin{array}{l}\text { Nivel } 1 / \\
\text { Level } 1\end{array}$ & $\begin{array}{l}\text { Selección muestras y cuantificación materiales / } \\
\text { Sample selection \& material quantification }\end{array}$ & $\begin{array}{l}\text { E1.1: Definición de los MCHs / CCM definition } \\
\text { E1.2: Elección de las muestras / Sanple selecion } \\
\text { E1.3: Cuantificación de recursos / Quantification resources }\end{array}$ & $\begin{array}{l}\text { Etapa } 1 / \\
\text { Stage } 1\end{array}$ \\
\hline $\begin{array}{l}\text { Nivel } 2 \text { / } \\
\text { Level } 2\end{array}$ & $\begin{array}{l}\text { Consumo energético por material / } \\
\text { Energy consumption per material }\end{array}$ & $\begin{array}{l}\text { E2.1: Determinación de CBMs / BMC Determination } \\
\text { E2.2: Caracterización cuantitativa de CBMs / Quantitative } \\
\text { charaterization of BMC } \\
\text { E2.3: Determinación consumo enegético / Energy consumption } \\
\text { determination }\end{array}$ & $\begin{array}{l}\text { Etapa } 2 \text { I } \\
\text { Stage } 2\end{array}$ \\
\hline $\begin{array}{l}\text { Nivel } 3 \text { / } \\
\text { Level } 3\end{array}$ & $\begin{array}{c}\text { Cuantificación consumo energético en los MCHs / } \\
\text { Quantification energy consumption }\end{array}$ & $\begin{array}{l}\text { E3.1: Consumo por } \mathrm{m}^{2} \text { construido / Consumption per } \mathrm{m}^{2} \\
\text { E3.2: Coeficientes relación entre imágenes / Relation coeficients } \\
\text { between images }\end{array}$ & $\begin{array}{l}\text { Etapa } 3 / \\
\text { Stage } 3\end{array}$ \\
\hline
\end{tabular}

Figura 2. Esquema metodológico.

Figure 2. Methodological Scheme. 
Urbanismo de Sevilla y archivos municipales, de los proyectos de ejecución que solicitaron licencia entre los años 2003-2010.

Los Modelos Constructivos Habituales quedarán definidos por las siguientes tipologías, que responden a las condiciones de habitabilidad de un clima mediterráneo levemente continentalizado, con precipitaciones variables, veranos secos muy cálidos e inviernos suaves, de temperatura media anual $18,6^{\circ} \mathrm{C}$ y precipitaciones medias de $534 \mathrm{~mm}$ al año:

- El bloque residencial destinado a viviendas de protección oficial VPO, constituido por cuatro plantas sobre rasante y una de sótano, con una disposición sobre la parcela exento, geometría de manzana cerrada con patio interior, con una superficie construida en torno a los $11.000-12.000 \mathrm{~m}^{2}$, albergando un total de 82-86 viviendas. Las características constructivas de esta tipología están constituidas por: losa de hormigón armado en cimentación, estructura vertical de pilares de hormigón con forjado unidireccional, cubierta plana, cerramiento de material cerámico de ladrillo y carpintería exterior de aluminio.

- Viviendas unifamiliares adosadas, constituidas por dos plantas sobre rasante, con patio trasero, con una superficie construida total de la promoción en torno a los 3.704-5.500 $\mathrm{m}^{2}$, albergando un total de 35-50 viviendas, unos $105-110 \mathrm{~m}^{2}$ construidos por vivienda. Las características constructivas de esta tipología son: zapatas de hormigón armado en cimentación, estructura vertical de pilares de hormigón con forjado unidireccional, cubierta plana e inclinada en castillete, cerramiento de material cerámico de ladrillo y carpintería exterior de aluminio.

b. Elección de las muestras. Las muestras seleccionadas, cuyas características tipológicas y constructivas de los proyectos objeto de estudio son representativas de las que identifican los MCHs definidos, son tomadas de los proyectos de ejecución de los archivos municipales para las viviendas unifamiliares y de la Empresa Municipal de la Vivienda de Sevilla (EMVISESA) para los bloques en altu$\mathrm{ra}$, en un total de diez proyectos para cada $\mathrm{MCH}$. Las denominaremos $\mathrm{MCH}_{1}$ para las viviendas unifamiliares adosadas, y $\mathrm{MCH}_{2}$ para los bloques residenciales en altura cuyas, ver imágenes en Figura 3.

c. Cuantificación de los recursos consumidos en las muestras seleccionadas. Se utiliza para ello la transferencia de la medición como herramienta y el programa informático de mediciones y presupuestos PRESTO V.7 (17), atendiendo a su vez al sistema de clasificación y codificación propuesto por la Base de Costes de la Construcción de Andalucía, BCCA (18), al ser la base de datos más utilizada en los proyectos de ejecución desarrollados en esta comunidad autónoma. archives, specifically from the projects that applied for licenses between 2003-2010.

The Common Construction Models (CCMs) will be defined by types defined below, which respond to the living conditions of as lightly continental Mediterranean weather, with variable rainfall, very hot dry summers and mild winters. The average annual temperature is $18.6^{\circ} \mathrm{C}$ and average rainfall $534 \mathrm{~mm}$ per year:

- The residential block for social housing, with four floors above ground and a basement, closed but with inner courtyard, involving a floor area around 11000-12000 $\mathrm{m}^{2}$ and hosting a total of 82-86 houses. The construction features of this type consist of: reinforced concrete slab foundation, vertical structure of concrete pillars with wrought-way, flat roof, cladding ceramic brick and exterior carpentry.

- Semidetached single-family homes consisting of two floors above ground, with backyard and with an overall built area about 3704-5500 $\mathrm{m}^{2}$, hosting a total of 35-50 houses, some of 105-110 $\mathrm{m}^{2}$ per dwelling. The design features of this type are: reinforced shallow foundations, vertical structure of concrete pillars with wrought-way, flat roof and sloped headframe, ceramic cladding and brick exterior carpentry.

b. Samples Selection. The selected samples, according to the typological constructive characteristics of the projects to be studied, are representative of those that identify the CCMs defined. They are taken from executed projects from municipal records for single-family dwellings and from the Municipal Company for Housing of Seville (Empresa Municipal de la Vivienda de SevillaEMVISESA) for blocks in height, in a total of ten projects for each CCM. CCM 1 has been defined for terraced houses and $\mathrm{CCM}_{2}$ for residential blocks in height (view images in Figure 3).

c. Quantification of the consumed resources in the selected samples. It is carried out by the measurement transfer as a tool and by the measurement software PRESTO V.7 (17). It corresponds to the classification and coding system proposed by the Andalusian Construction Cost of Database (Base de Costes de la Construcción de Andalucía, BCCA) (18), being the most used database of the projects developed in this region. 


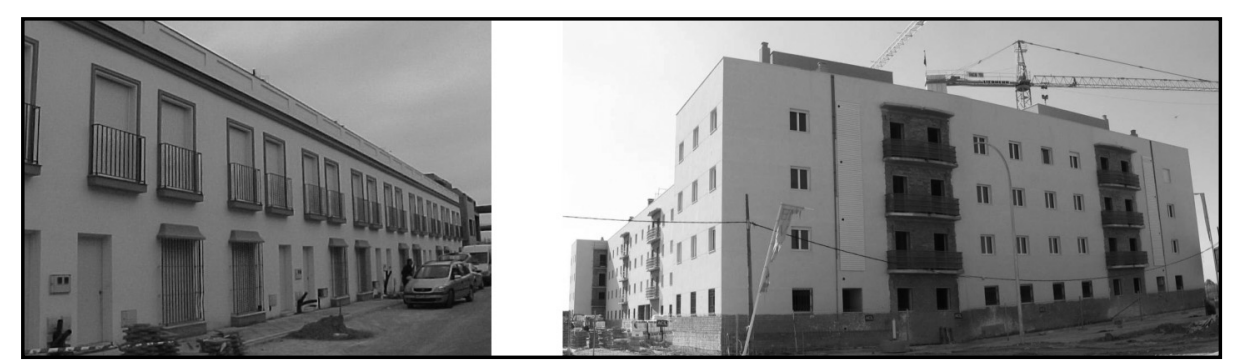

Figura 3. Imágenes ilustrativas de los modelos de construcción habituales en Sevilla, $\mathrm{MCH}_{1}$ y $\mathrm{MCH}_{2}$. Figure 3. Common Constructive Model in Seville, illustrative images, $\mathrm{CCM}_{1}$ y $\mathrm{CCM}_{2}$.

Esta subetapas recoge la cuantificación de la totalidad de recursos materiales consumidos en cada una las muestras seleccionadas representativas de los MCHs, fruto de la normalización en peso por $\mathrm{m}^{2}$ construido $\left(\mathrm{kg} / \mathrm{m}^{2}\right)$ de cada componente básico material empleado en la ejecución de los diez proyectos de ejecución que constituyen cada una de las dos muestras, $\mathrm{MCH}_{1}$ y $\mathrm{MCH}_{2}$.

La normalización de las unidades resultantes permite obtener resultados comparables, al transformar la unidad origen, unidad de medida del elemento, a la unidad de destino, el peso en $\mathrm{kg}$ del elemento, mediante la aplicación, a cada componente básico material de la muestra de un Coeficiente de Transformación (Ct), que representa el peso por la unidad de referencia del elemento (12). El Ct se obtiene a partir de cuatro fuentes de información en función del material de construcción con el que nos encontremos y por el siguiente orden de prioridad:

Fuente 1: densidad aparente del material de construcción.

Fuente 2: muestra pesada en báscula en el lugar de suministro.

Fuente 3: información comercial, en este caso el peso del recurso material es la media aritmética de los pesos obtenidos para el mismo material de construcción en tres informaciones comerciales diferentes.

Etapa 2. En esta etapa se especifican los valores correspondientes al consumo energético requerido en el proceso de fabricación de cada uno de los Componentes Básicos Materiales (CBMs) consumidos en la ejecución de las tipologías constructivas definidas como $\mathrm{MCH}_{1}$ y $\mathrm{MCH}_{2}$, expresados en $\mathrm{MJ} / \mathrm{kg}$.

a. Determinación de componentes básicos materiales representativos de las muestras. La estrategia a seguir consiste en definir la Imagen de Referencia del $\mathrm{MCH}$ (19), mediante la aplicación de un conjunto de "normas" a los CBMs consumidos en su ejecución y determinados en la subetapa 1.3, que permitan sintetizar la información de mayor relevancia, lo que dará lugar a la elección de forma justificada de los CBMs representativos de cada una de las muestras, $\mathrm{MCH}_{1}$ y $\mathrm{MCH}_{2}$.
This sub-step involves the quantification of the overall resources consumed in each of the selected samples representing CCMs and resulting from the normalization in weight per $\mathrm{m}^{2}$ constructed $\left(\mathrm{kg} / \mathrm{m}^{2}\right)$ of each basic material used in the execution of the ten projects selected per each sample (of the CCM 2 and the $C C M_{1}$ ).

The normalization of the resulting units allow us to obtain comparable results by transforming the source unit -he measurement unit of the element-, to the destination unit, weight in $\mathrm{kg}$ of the element, by applying a Transformation coefficient (TC) to each basic material of the sample, which represents the weight per reference unit of the element (12). The Tc is obtained from four sources of information in terms of the building materials we can find. They are disposed in the following order of priority:

\section{Source 1: Apparent density of the construction} material.

Source 2: Scale weighing sample in the place of supply.

Source 3: Business information. In this case the weight of material resource is the arithmetic mean of the weights obtained for the same building material in three different commercial reports.

Step 2. At this stage, values are specified for the energy consumption required in the manufacturing process of each of the Basic Material Components (BMCS) consumed in the implementation of the construction types defined as $C C M_{1}$ and $C C M_{2}$, and expressed in $\mathrm{MJ} / \mathrm{kg}$.

a. Determination of basic components of representative material samples. The strategy here is to define the CCM Reference Image (19), by applying a set of "rules" for the BMCs consumed in its execution and determined in the sub-step 1.3, allowing the synthesis of the most relevant information. This will lead to a justified choice of representative BMCs for each of the samples $\left(C C M_{1}\right.$ and $\mathrm{CCM}_{2}$ ). 
Las "normas de aplicación" obtenidas al efecto son consecuencia de un proceso de revisión que ha considerado: el peso por $\mathrm{m}^{2}$ de los materiales dentro de la edificación, el consumo energético requerido en su transformación en producto de construcción, el coeficiente de participación del material en la muestra y aplicación del intervalo intercuartílico, que recoge el $75 \%$ de los recorridos centrales de las variables en cada CBM de la muestra, eliminando los extremos; esto es, los valores máximos y mínimos. El resultado concluye con las siguientes normas:

- Agrupación de CBMs por similitud de características físico-químicas entre el material constructivo origen y el de destino.

- Agrupación de CBMs por cuanto el consumo energético requerido en su fabricación es similar y por consiguiente el impacto ambiental que genera su proceso de transformación.

- Eliminación de CBMs no representativos de la muestra, por aparecer a lo sumo en dos de los diez proyectos de ejecución estudiados en cada muestra. Dado que la muestra está constituida por diez proyectos de ejecución, el intervalo intercuartílico se corresponderá con el $80 \%$ al optar por eliminar tan solo dos valores extremos, el mínimo y el máximo. Los valores extremos no considerados se suponen que se comportan como la media, teniendo en cuenta su peso en la etapa siguiente.

b. Caracterización cuantitativa de los CBMs de las muestras. En esta subetapa se caracterizan cuantitativamente los CBMs que constituyen la Imagen de Referencia de los MCHs, mediante la determinación de la variable: peso medio por $\mathrm{m}^{2}$ construido ( $\mathrm{R}^{*}$ ) de cada CBM. Utilizaremos para ello el programa de tratamiento de datos y análisis estadístico denominado Statical Product and Service Solutions (20), que nos proporcionará los extremos del intervalo intercuartílico, valores máximos y mínimos de cada CBM en cada uno de los diez proyectos de ejecución que constituyen cada una de las muestras, $\mathrm{MCH}_{1}$ y $\mathrm{MCH}_{2}$, a la vez que determinará el peso medio de cada CBM mediante la aplicación de la siguiente fórmula [1], la media aritmética de los valores centrales del recorrido de las variables, eliminados los extremos del intervalo intercuartílico de Beeston.
The "Implementing Rules" obtained are the result of a review process that has considered the following aspects: the weight per $\mathrm{m}^{2}$ of the materials inside the building, the energy consumption required in their transformation to a product of construction, the participation rate of the material in the sample and the application of the interquartile range, which includes $75 \%$ of central paths of the variables in each BMC of the sample, avoiding the extremes, i.e. the maximum and minimum values. The result concludes with the following standards:

- Grouping of BMCs by similarity of physico-chemical characteristics between the building material of origin and destination.

- Grouping BMCs in that the energy consumption required in their manufacture is similar and therefore the environmental impact generated by their transformation process.

- Removal of BMCs unrepresentative of the sample, as they appear at most in two of the ten projects studied in each sample run. Since the sample consists of ten projects for implementation, the interquartile range will correspond to $80 \%$, by avoiding just the two extreme values, the minimum and maximum. The extreme values not considered are supposed to behave as the mean, taking into account their weight in the next step.

b. Quantitative description of the BMCs of the samples. In this sub-stage the BMCs constituting the reference image for the CCMs are quantitatively represented, by determining the following variable: the average weight per $m^{2}$ built $\left(R^{*}\right)$ of each BMC. To conduct it, we will use the program for data processing and statistical analysis called statical Product and Service Solutions (20), which will provide us the extremes of the interquartile range (in other words, the minimum and maximum values ??of each $B M C$ in each of the ten projects for the two samples: $C_{C C} M_{1}$ and $\left(C M_{2}\right)$. Furthermore, it will determine the average weight of each BMC by applying the following formula [1], the arithmetic mean of the core values ??of the variables of the course, removed the extremes of the interquartile range of Beeston.

$$
\mathrm{R}^{*}={ }^{\mathrm{TM}} \mathrm{S}[\mathrm{Rs}-\mathrm{Rsmax}-\mathrm{Rsmín}] / 8
$$

c. Determinación del consumo energético por componente básico material. La estrategia llevada a cabo para lograr nuestros objetivos consistirá en establecer un conjunto de hipótesis que nos permitan adaptar la información medioambiental disponible a la Imagen de Referencia de cada $\mathrm{MCH}$, para determinar el consumo energético de los CBMs que los constituyen. Se trata de un total de c. Determination of energy consumption per Basic Material Component. The strategy implemented to achieve our goals is to establish a set of assumptions that allow us to adapt to environmental information available to the image of each CCM Reference in order to determine the energy consumption of the BMCs that constitute them. This implies a sum of one hundred sixty 
ciento sesenta y ocho materiales empleados en la construcción de edificios (12), de los que se dispone en la actualidad del consumo energético requerido en el proceso de fabricación de $1 \mathrm{~kg}$ de material, expresados en $\mathrm{MJ} / \mathrm{kg}$, procedente de auditorias realizadas a empresas del sector de la construcción y que ha servido de base para la constitución del banco BEDEC PR/PCT del ITeC (15).

Se analizan las características físico-químicas del conjunto de variables, concretando la estructura de constitución de cada CBM; esto es, la materia prima que conforma el material de referencia, lo que nos permitirá establecer un conjunto de hipótesis que nos admita asignar los valores medioambientales disponibles considerados equivalentes. Son las siguientes:

Hipótesis 1: componentes básicos materiales (CBMs) constituidos por materia prima pura. En este caso los valores asignados para el consumo energético son los correspondientes a la materia prima pura disponible en la fuente de información medioambiental.

Hipótesis 2: componentes básicos materiales mixtos con prevalencia de uno de sus materiales constitutivos en su composición química. En este caso el valor medioambiental asignado a dicho CBM es el del elemento más relevante, no considerándose el de menor entidad.

Hipótesis 3: componentes básicos materiales mixtos puros. Los constituidos a lo sumo por dos materias primas diferentes. En estos casos le serán de aplicación valores medioambientales correspondientes a auditorías realizadas a diferentes empresas del sector destinadas a la fabricación de los CBMs citados, contrastadas con las publicadas en la base de datos BEDEC del ITeC (15).

Hipótesis 4: componentes básicos materiales equivalentes. Se aplica en aquellos CBMs representativos de la muestra cuyas características físico-químicas no quedan definidas expresamente en los epígrafes de las mediciones de los proyectos de ejecución de los que proceden. En este caso suponemos que la materia prima que lo constituye es un material equivalente en el listado de valores medioambientales del ITeC del que tomamos su valor de consumo energético.

Etapa 3. En esta etapa se cuantifican el consumo energético requerido en la ejecución de cada una de las tipologías constructivas definidas como las habituales (MCHs), consecuencia de la fabricación de los recursos materiales empleados en su construcción, siendo necesario el desarrollo pormenorizado de las siguientes subetapas:

a. Consumo energético por $\mathrm{m}^{2}$ construido. Para determinar el consumo energético por $\mathrm{m}^{2}$ construido (CECs) correspondiente a cada uno de los CBMs representativos de los MCHs que definen las respectivas Imágenes de eight materials used in building construction (12). Currently, it is available the data of their energy consumption required in the manufacturing process of 1 $\mathrm{kg}$ of material, expressed in $\mathrm{MJ} / \mathrm{kg}$, due to the audits conducted on businesses of the construction sector, providing thus the database for the bank BEDEC PR/PCT ITeC (15).

We analyze the physical and chemical characteristics of the set of variables, specifying the structure that sets up each BMC (i.e. the raw material that forms the reference material). As a result, we can establish a set of hypotheses assignable to the environmental values available and considered equivalent. They are expressed below:

Hypothesis 1: basic materials components (BMCs) set up by pure raw material. In this case the values assigned to energy consumption are those for pure raw material available according to our source of environmental information.

Hypothesis 2: basic components mixed materials with prevalence of one of their constituent materials in their chemical composition. In this case, the environmental value assigned to that BMC is the one of the most relevant element, not considering the minor.

Hypothesis 3: basic components mixed pure materials. Two different raw materials constitute the mat the most. For them, we apply environmental values according to the audits carried out to different companies responsible for the manufacture of the CBMs mentioned, contrasted with those published in the database of ITEC BEDEC (15).

Hypothesis 4: basic components equivalent materials. It is applied to those representative BMCs with physicochemical characteristics not explicitly defined in the headings of the projects they come from. In this case, we assume that the raw material that constitutes them is equivalent materials, according to the list of environmental values of the ITeC from which we took their energy consumption value.

Step 3. At this stage, the energy consumption required in the execution of each of the types defined as the usual constructive types (CCMs) is quantified. It is a consequence of the manufacture of material resources used in the construction. For this reason, we need the development of the following sub-steps:

a. Energy consumption per $m^{2}$ built. To determine the energy consumption per $\mathrm{m}^{2}$ constructed (ECCS) corresponding to each BMC representative of the CCMs, which define the respective reference images, it will be 
Referencia, será necesario aplicar los resultados obtenidos en la subetapa 2.2., correspondientes al peso medio por $\mathrm{m}^{2}$ construido de cada CBM de las muestras $\left(\mathrm{R}^{*} \mathrm{~s}\right)$, a los valores de consumo energético por material (CEs) obtenidos en la subetapa 2.3., obteniendo así los resultados deseados expresados en $\mathrm{MJ} / \mathrm{m}^{2}$ de construido. Lo que se define mediante la aplicación de la fórmula siguiente [2]: necessary to apply the results obtained in the sub-step 2.2. to the ones obtained in the sub-step 2.3. In other words, we need to apply the average weight per $\mathrm{m}^{2}$ constructed of each BMC of the samples ( $\left.R^{*} s\right)$ to the values of energy consumption by material (ECS). As a result, we obtain the desired results expressed in $\mathrm{MJ} / \mathrm{m}^{2}$ of built. It is defined by applying the following formula [2]:

$$
\mathrm{CEC}_{\mathrm{S}}=\mathrm{CE}_{\mathrm{S}} \times \mathrm{R}^{*} \mathrm{~S}
$$

b. Coeficientes de relación entre imágenes. La estrategia utilizada en esta subetapa para lograr el objetivo principal consistirá en extrapolar los resultados obtenidos para la Imagen de Referencia de cada $\mathrm{MCH}$ a su Imagen Original, la que recoge la totalidad de los CBMs de la muestra, mediante la determinación de lo que denominaremos coeficiente de relación entre imágenes, que nos permitirán calcular la distancia $(\delta)$ que separa el $\mathrm{MCH}$ del conjunto de normas contenidas en su Imagen de Referencia, denominándose CRce, Coeficiente de Relación consumo energético, proceso que permitirá cuantificar el consumo energético en la construcción de cada $\mathrm{MCH}$ definido en Sevilla, expresado en $\mathrm{MJ} / \mathrm{m}^{2}$ construido.

Analíticamente el Coeficiente de Relación consumo energético (CRce) será el resultado de dividir el consumo energético medio (CEC), y el peso medio por $\mathrm{m}^{2}\left(\mathrm{R}^{*}\right)$ que suponen los recursos materiales consumidos en su correspondiente Imagen de Referencia, obteniendo los resultados en $\mathrm{MJ} / \mathrm{kg}$, mediante la siguiente relación [3]: b. Correlation Coefficient between images. The strategy used in this sub-step to achieve the main objective will be to extrapolate the results to the reference image of each CCM to its original image, which includes all the BMCs of the sample. It will be done by determining what we will call correlation coefficient between images, which will allow us to calculate the distance $(\delta)$ that separates the CCM from the set of rules contained in the reference image, i.e. $C C_{E C}$ : correlation coefficient of energy consumption ratio, a process that will quantify the energy consumption in the construction of every CCM defined in Seville, expressed in $\mathrm{MJ} / \mathrm{m}^{2}$ built.

Analytically the energy ratio coefficient $\left(C C_{E C}\right)$ will be the result of dividing the average energy consumption (ECC) and the average weight per $m^{2}\left(R^{*}\right)$ involving material resources consumed in the corresponding reference image. The results are obtained in $\mathrm{MJ} / \mathrm{kg}$, following the relation below [3]:

$$
\text { CRce }=\delta=\text { CEC } / R^{*}
$$

Finalmente multiplicando los valores correspondientes a cada una de las Imágenes de Referencia en la dimensión consumo energético por su respectivo Coeficiente de Relación (CRce), habremos corregido la desviación existente entre las imágenes comparadas, debidas al vacío de información que supone la eliminación en la Imagen de Referencia de los CBMs marginales, dando cumplimiento al objetivo principal de la presente investigación, la cuantificación del consumo energético, expresado en $\mathrm{MJ} / \mathrm{m}^{2}$.

\section{RESULTADOS}

La aplicación de la metodología expuesta en el apartado anterior a cada una de las muestras, los Modelos Constructivos Habituales definidos en Sevilla, $\mathrm{MCH}_{1}$ para las viviendas unifamiliares adosadas de dos plantas de altura y $\mathrm{MCH}_{2}$ para los bloques residenciales de cuatro plantas de altura, destinados a viviendas de protección oficial, nos proporcionan los resultados expuestos en la Tabla 1, donde se realiza una comparativa tanto en peso por $\mathrm{m}^{2}$ construido como del consumo energético, expresado en $\mathrm{MJ} / \mathrm{m}^{2}$
Finally, multiplying the values for each reference images in the energy dimension by their respective correlation coefficient ratio $\left(C C_{E C}\right)$, we will have corrected the deviation between compared images, due to the lack of information that involves the removal in the reference Image of the marginal BMCs. Thus, we fulfil the main objective of this research: the quantification of energy consumption, expressed in $\mathrm{MJ} / \mathrm{m}^{2}$.

\section{RESULTS}

The application of the methodology exposed in the previous section to each of the samples, i.e., the two Common Construction Models defined in Seville (first, $\mathrm{CCM}_{1}$ for single-family terraced houses of two storeys high; and second, the $\mathrm{CCM}_{2}$ for residential blocks of four storeys high for subsidized housing), provides us the results shown in Table 1. It shows a comparison both of the weight per $\mathrm{m}^{2}$ constructed and of the energy consumption, expressed in $\mathrm{MJ} / \mathrm{m}^{2}$ constructed, between 
Tabla 1 / Table 1

Comparativa de consumo energético por recurso material en los MCHs definidos. Comparison of energy consumption by material resource defined in CCM.

\begin{tabular}{|c|c|c|c|c|c|c|c|}
\hline \multirow{2}{*}{$\begin{array}{l}\text { Recurso material consumido (CBM) / } \\
\text { Resource material consumed (BMC) }\end{array}$} & \multicolumn{2}{|c|}{$R^{*}\left(\mathrm{Kg} / \mathrm{m}^{2}\right)$} & \multirow{2}{*}{\begin{tabular}{|l|}
$\mathrm{CE} / \mathrm{EC}(\mathrm{MJ} / \mathrm{Kg})$ \\
$\mathrm{MCH}_{1,2} / \mathrm{CCM}_{1,2}$ \\
\end{tabular}} & \multicolumn{2}{|c|}{ CEC / ECC $\left(\mathrm{MJ} / \mathrm{m}^{2}\right)$} & \multicolumn{2}{|c|}{$\%$ CEC / ECC } \\
\hline & $\mathrm{MCH}_{1} / \mathrm{CCM}_{1}$ & $\mathrm{MCH}_{2} / \mathrm{CCM}_{2}$ & & $\mathrm{MCH}_{1} / \mathrm{CCM}_{1}$ & $\mathrm{MCH}_{2} / \mathrm{CCM}_{2}$ & $\mathrm{MCH}_{1} / \mathrm{CCM}_{1}$ & $\mathrm{MCH}_{2} / \mathrm{CCM}_{2}$ \\
\hline Acero / Steel & 47.25 & 39.70 & 35.00 & 1679.70 & 1.439 .01 & 16.06 & 16.27 \\
\hline Agua / Water & 106.33 & 126.24 & 0.00 & 5.32 & 6.31 & 0.05 & 0.07 \\
\hline Aluminio / Aluminium & 0.57 & 0.70 & 218.00 & 124.47 & 152.15 & 1.19 & 1.72 \\
\hline Áridos / Aggregates & 1174.41 & 529.55 & 0.01 & 120.43 & 103.47 & 1.15 & 1.17 \\
\hline Asfaltos y betunes / Asphalt\&Bitumen & 0.30 & 1.19 & 45.43 & 13.51 & 121.18 & 0.13 & 1.37 \\
\hline Cementos / Cements & 47.24 & 30.68 & 4.36 & 205.97 & 131.82 & 1.97 & 1.49 \\
\hline Gres, porcelana / Glazed Ceramics & 70.37 & 1.15 & 8.35 & 601.52 & 31.22 & 5.75 & 0.35 \\
\hline Hormigón / Concrete & 1006.43 & 1071.23 & 2.30 & 2314.78 & 2463.83 & 22.13 & 27.86 \\
\hline Madera / Wood & 5.88 & 4.42 & 2.10 & 12.34 & 14.30 & 0.12 & 0.16 \\
\hline Materiales cerámicos/ Ceramic material & 342.90 & 168.95 & 2.32 & 794.34 & 451.52 & 7.59 & 5.11 \\
\hline $\begin{array}{c}\text { Otros metales (cobre, bronce, latón, } \\
\text { plomo) / Other metals (copper, bronze, } \\
\text { brass, lead) }\end{array}$ & 0.77 & 1.97 & 160.00 & 124.70 & 251.34 & 1.19 & 2.84 \\
\hline Pinturas y sellantes / Paints\&Sealants & 0.35 & 2.40 & 20.00 & 6.96 & 59.99 & 0.07 & 0.68 \\
\hline Plásticos y resinas / Plastics\&Resins & 11.01 & 5.16 & 102.00 & 1.226 .74 & 306.56 & 11.73 & 3.47 \\
\hline $\begin{array}{l}\text { Hormigón prefabricado / } \\
\text { Precast Concrete }\end{array}$ & 20.75 & 100.77 & 111.40 & 2149.56 & 1668.51 & 20.55 & 18.87 \\
\hline PVC / PVC & 3.56 & 1.38 & 70.00 & 249.12 & 96.88 & 2.38 & 1.10 \\
\hline Sintéticos y aceites / Synthetics\&Oils & 5.51 & 12.70 & 100.00 & 549.42 & 1.193 .89 & 5.25 & 13.50 \\
\hline Vidrio / Glass & 3.66 & 1.28 & 15.90 & 58.17 & 21.39 & 0.56 & 0.24 \\
\hline Yeso, limos / Gypsum, Lime & 86.73 & 48.14 & 2.57 & 223.98 & 330.54 & 2.14 & 3.74 \\
\hline Totales / Total & 2934.00 & 2147.61 & & 10461.02 & 8843.90 & 100.00 & 100.00 \\
\hline
\end{tabular}

construido, en cada MCH por cada uno de los CBMs habitualmente consumidos en su ejecución, con lo que podemos observar los más relevantes en cuanto al impacto ambiental generado, consecuencia del consumo energético requerido en su proceso de fabricación.

La Tabla 1 queda configurada de la forma siguiente, la primera columna recoge los CBMs que constituyen la Imagen de Referencia de los MCHs, resultado de la aplicación de la etapa 2.1 y 2.3 de la metodología. En la segunda columna se indican los pesos medios que caracterizan a cada CBM, expresados en $\mathrm{kg} / \mathrm{m}^{2}$ construido, a fin de establecer comparativas entre las tipologías definidas, eliminando el efecto negativo del tamaño de la muestra. La tercera columna señala los valores correspondientes al consumo energético de cada CBM, requerido en la fabricación de $1 \mathrm{~kg}$ de cada uno de los componentes básicos materiales que constituyen la Imagen de Referencia de los MCHs definidos y en consecuencia consumidos en su ejecución, obtenidos en la etapa 2.3. La cuarta columna expresa los valores anteriores por $\mathrm{m}^{2}$ construido para cada $\mathrm{MCH}$. Por último, la quinta columna identifica el porcentaje que ocupan en la edificación cada Componente Básico Material, en relación con el consumo energético señalado en la columna anterior.

Gráficamente los porcentajes obtenidos para el consumo energético por componente básico material en cada $\mathrm{MCH}$, queda representado en la Figura 4: each CCM and each of the BMCs commonly consumed in their implementation. Thus, we can observe the most relevant data in terms of environmental impact caused as a consequence of energy consumption required in the manufacturing process.

Table 1 is configured as follows; the first column contains the BMCs that are the reference image of the CCMs, resulting from the implementation of phase 2.1 and 2.3 of the methodology. The second column shows the average weights characterizing each BMC, expressed in $\mathrm{kg} / \mathrm{m}^{2}$ constructed, in order to establish different comparisons between the types defined, eliminating the negative effect of the sample size. The third column indicates the energy consumption values for each $B M C$, required in the manufacture of $1 \mathrm{~kg}$ of each basic component materials from which sets up the reference image of the CCMs defined and consequently consumed in their construction, and obtained in step 2.3. The fourth column expresses the above values per $m^{2}$ built for each CCM. Finally, the fifth column identifies the percentage they represent in the building of each basic component material in relation to the energy consumption reported in the previous column.

The rates obtained for the energy consumption per basic component material in each CCM are graphically represented in Figure 4 below: 


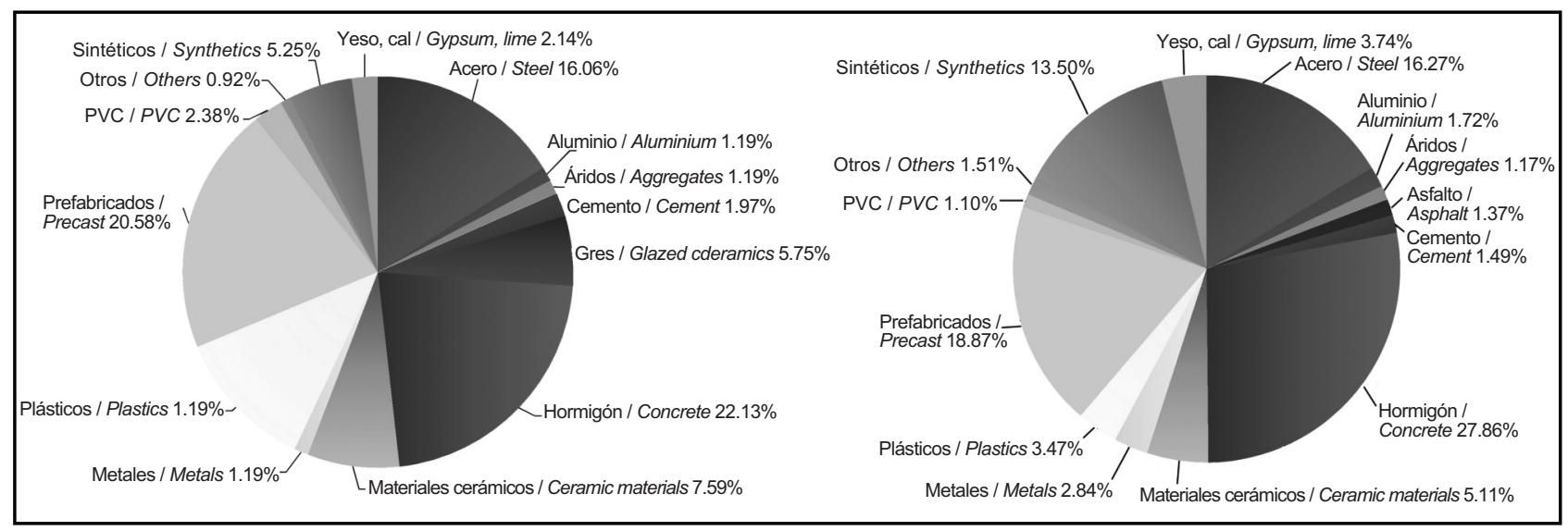

Figura 4. Representación de los $\mathrm{CBMs}$ que suponen mayor consumo energético. De derecha a izquierda $\mathrm{MCH}_{1}$ y $\mathrm{MCH}_{2}$, respectivamente. Figure 4. Representation of the energy consumption of BMCs. From right to left $C_{C M}$ and $C C M_{2}$, respectively.

Del mismo modo, si realizamos una comparativa para cada $\mathrm{MCH}$, por subsistemas constructivos, cuyos valores se reflejan en la Tabla 2, podemos observar los que requieren de un mayor consumo energético, sirviendo en consecuencia de modelo sobre el que ensayar soluciones constructivas alternativas a las convencionales, consideradas ecoeficientes, en definitiva cumpliéndose el objetivo principal de establecer una diagnosis del impacto ambiental ocasionado por los modelos constructivos considerados más habituales, desde la óptica del consumo energético derivado del proceso de fabricación de los recursos materiales habitualmente consumidos en su ejecución.
Similarly, Table 2 shows a comparison for each CCM regarding the building subsystems. There, we can observe those which require more energy consumption. As a result, it may be useful as a model on which to test alternatives to conventional constructive solutions, in other words, to look for eco-efficient solutions. Ultimately, we fulfil the primary objective of establishing a diagnosis of the environmental impact caused by building models considered common, from the standpoint of energy consumption derived from the manufacturing process of material resources usually consumed in their construction.

Tabla 2 / Table 2

Comparativa de consumo energético por subsistema constructivo en los MCHs definidos. Comparison of energy consumption per constructive subsystem defined at CCMs.

\begin{tabular}{|c|c|c|c|c|c|c|}
\hline \multirow{2}{*}{$\begin{array}{l}\text { Subsistemas constructivos I } \\
\text { Constructive subsystems }\end{array}$} & \multicolumn{2}{|c|}{$R^{*}\left(K g / m^{2}\right)$} & \multicolumn{2}{|c|}{$\operatorname{CEC} / E C C\left(\mathrm{MJ} / \mathrm{m}^{2}\right)$} & \multicolumn{2}{|c|}{$\%$ CEC / ECC } \\
\hline & $\mathrm{MCH}_{1} / \mathrm{CCM}_{1}$ & $\mathrm{MCH}_{2} / \mathrm{CCM}_{2}$ & $\mathrm{MCH}_{1} / \mathrm{CCM}_{1}$ & $\mathrm{MCH}_{2} / \mathrm{CCM}_{2}$ & $\mathrm{MCH}_{1} / \mathrm{CCM}_{1}$ & $\mathrm{MCH}_{2} / \mathrm{CCM}_{2}$ \\
\hline Movimientos tierras / Earthwork & 0.00 & 166.19 & 0.00 & 14.49 & 0.00 & 0.16 \\
\hline Cimentación / Foundation & 494.73 & 766.95 & 818.31 & 1627.02 & 7.82 & 18.40 \\
\hline Saneamiento / Drainage & 121.73 & 1.19 & 193.45 & 41.91 & 1.85 & 0.56 \\
\hline Estructura / Structure & 1006.12 & 640.53 & 6074.79 & 3475.50 & 58.07 & 39.30 \\
\hline Cubierta / Roof & 320.83 & 99.38 & 673.93 & 205.87 & 6.44 & 2.33 \\
\hline Cerramientos / Building envelope & 709.64 & 268.72 & 818.31 & 2.039 .33 & 14.08 & 23.06 \\
\hline Instalaciones / Installations & 14.49 & 14.94 & 420.03 & 513.74 & 4.02 & 5.81 \\
\hline Carpintería metálica / Metalwork & 3.89 & 3.50 & 273.25 & 276.44 & 2.61 & 3.12 \\
\hline Carpintería de madera / Woodwork & 1.88 & 3.63 & 30.18 & 60.13 & 0.29 & 0.68 \\
\hline Vidrios / Glass & 5.40 & 2.86 & 266.89 & 210.44 & 2.55 & 2.38 \\
\hline Revestidos / Coating & 242.55 & 146.62 & 193.36 & 272.38 & 1.85 & 3.08 \\
\hline Decoración / Decoration & 0.01 & 3.83 & 2.20 & 13.92 & 0.02 & 0.16 \\
\hline Urbanización / Urbanization & 12.72 & 29.27 & 41.50 & 84.73 & 0.40 & 0.96 \\
\hline Totales / Total & 2934.00 & 2147.61 & 10461.02 & 8843.90 & 100 & 100 \\
\hline
\end{tabular}

Gráficamente los porcentajes obtenidos para el consumo energético por subsistema constructivo en cada $\mathrm{MCH}$ quedan representados en la Figura 5:
The rates obtained for the energy consumption per constructive subsystem in each CCM are graphically represented in the following figure 5 : 


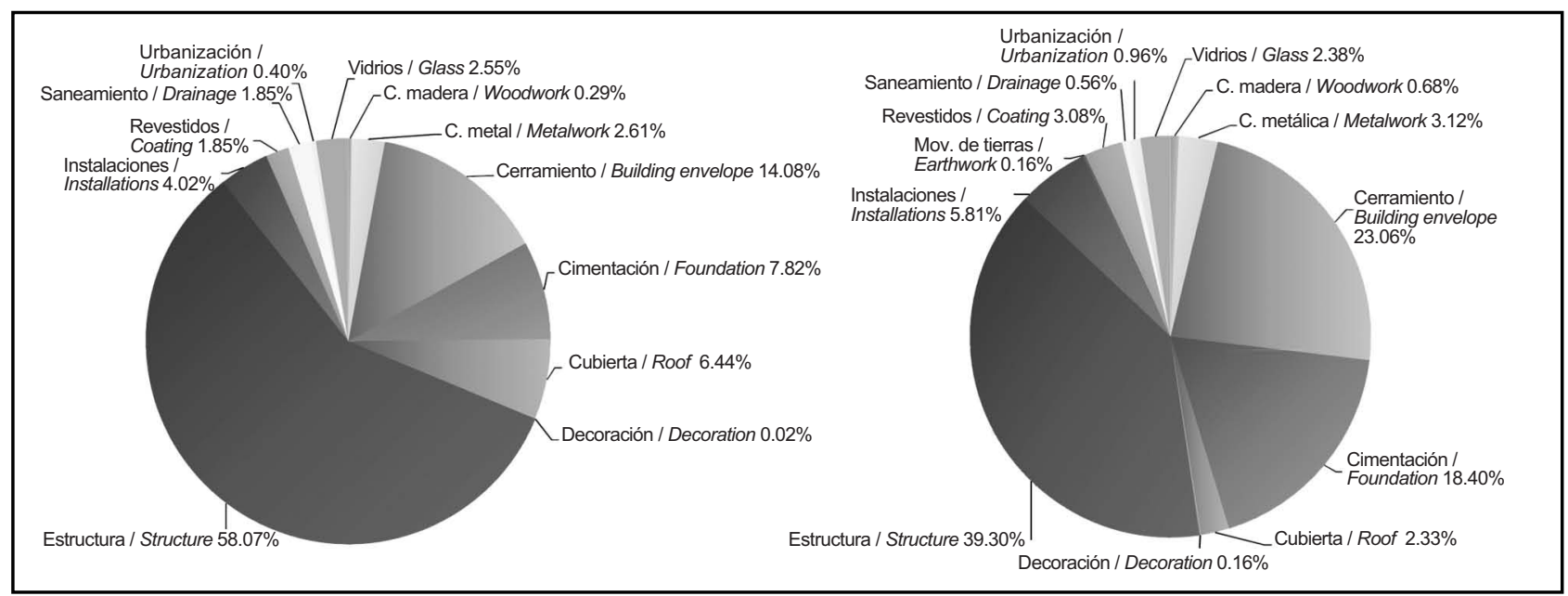

Figura 5. Representación del consumo energético por subsistemas constructivos. De derecha a izquierda $\mathrm{MCH}_{1}$ y $\mathrm{MCH}_{2}$, respectivamente. Figure 5. Representation of energy consumption for building subsystems. From right to left $\mathrm{CCM}_{1}$ and $\mathrm{CCM}_{2}$, respectively.

Los resultados obtenidos son en resumen los siguientes:

- El consumo energético requerido para la ejecución de las viviendas unifamiliares adosadas es de $10.461,02 \mathrm{MJ} / \mathrm{m}^{2}$ frente al bloque residencial en altura que cuenta con $8.843,90 \mathrm{MJ} / \mathrm{m}^{2}$.

- El subsistema constructivo que requiere de un mayor consumo energético consecuencia de los recursos materiales consumidos es la estructura de pilares de hormigón armado y forjado unidireccional de viguetas de hormigón, con un consumo de $6.074,79 \mathrm{MJ} / \mathrm{m}^{2}$ en el $\mathrm{MCH}_{1}$ frente a $3.475,50 \mathrm{MJ} / \mathrm{m}^{2}$ en el $\mathrm{MCH}_{2}$. Estos valores representan el $58,07 \%$ del consumo energético requerido por los materiales de construcción utilizados en el $\mathrm{MCH}_{1}$, mientras que se reducen a un $39,30 \%$ en el $\mathrm{MCH}_{2}$, esto es, en los edificios en altura.

- El peso por $\mathrm{m}^{2}$ construido de los recursos materiales consumidos en el $\mathrm{MCH}_{1}$ es de $2.934,00 \mathrm{~kg} / \mathrm{m}^{2}$ mientras es de $2.147,61 \mathrm{~kg} / \mathrm{m}^{2}$ en el $\mathrm{MCH}_{2}$.

- Los recursos materiales de mayor consumo energético son en ambos MCHs los hormigones, seguidos de sus prefabricados y los aceros, no guardando una relación directa con el peso que ocupan en la edificación.

\section{DISCUSIÓN}

El modelo generado ha permitido en este trabajo cuantificar el consumo energético, en $\mathrm{MJ} / \mathrm{m}^{2}$ construidos, en las tipologías constructivas definidas, consecuencia del proceso de fabricación de los recursos materiales consumidos en su ejecución, identificando los materiales de construcción y subsistemas constructivos de mayor impacto. Los resultados obtenidos constituyen una diagnosis de las tipologías definidas como las más habituales en el sector de la construcción, observando que los edificios
The results obtained are summarized as follows:

- The energy consumption required for the execution of the terraced houses is $\mathrm{MJ} / \mathrm{m}^{2} 10461.02$ versus the $\mathrm{MJ} / \mathrm{m}^{2} 8843.90$ necessary for residential block in height.

- The constructive subsystem that requires higher energy consumption as a consequence of the material resources consumed is the structure of reinforced concrete columns and joist slab of concrete, with a consumption of $6074.79 \mathrm{MJ} / \mathrm{m}^{2}$ in the $\mathrm{CCM}_{1}$ vs. $3475.50 \mathrm{MJ} / \mathrm{m}^{2}$ in the $\mathrm{CCM}_{2}$. These values represent $58.07 \%$ of the energy consumption required by the construction materials used in the $C C M_{1}$, while they decrease to $39.30 \%$ in the $C C M_{2}$, i.e. in tall buildings.

- The weight per $\mathrm{m}^{2}$ constructed of the material resources consumed in the $\mathrm{CCM}_{1}$ is $2934.00 \mathrm{~kg} / \mathrm{m}^{2}$ while it is $2147.61 \mathrm{~kg} / \mathrm{m}^{2}$ in the $\mathrm{CCM}_{2}$.

- The material resources with largest energy consumption are concrete in both CCMs followed by the prefabricated materials and the steel. They are not directly related to the weight they occupy in the building.

\section{DISCUSSION}

The model developed in this paper has enabled the quantification of the energy consumption in $\mathrm{MJ} / \mathrm{m}^{2}$ built, according the types of construction types defined by the manufacture process of the material resources consumed in their construction. This has been done identifying the construction materials and the building subsystems with greatest impact on the environment. The results obtained set up a diagnosis for the most common types of construction, noting that tall buildings 
en altura requieren de un menor consumo de recursos y por ende de un menor consumo energético frente a las viviendas de desarrollo horizontal.

En relación a los materiales de construcción utilizados, dado que las características constructivas de ambos modelos son similares, estructura de hormigón armado, forjados unidireccionales, cerramiento cerámico de ladrillo, carpintería de aluminio y cubierta plana transitable, los porcentajes son también muy similares. No obstante, la cubierta de las viviendas unifamiliares es mixta, al disponer de un castillete en cubierta de tejas, con lo que el consumo energético de este subsistema es superior al del bloque residencial. Por otro lado, la estructura de las viviendas unifamiliares requiere de un mayor consumo energético, esto es debido al tipo de cimentación, zapatas de hormigón armado con pilares enanos y forjado sanitario, lo que estaría directamente relacionado con el tipo de terreno sobre el que se cimienta.

En cuanto a los subsistemas constructivos, las diferencias en cuanto a la cimentación de las citadas tipologías, zapatas de hormigón en viviendas unifamiliares adosadas y losa de hormigón armado en edificios de altura, genera una disminución considerable en las primeras.

Observamos que los resultados obtenidos en trabajos similares realizados con diferentes fuentes de información y herramientas informáticas de análisis de ciclo de vida de los materiales, muestran semejanzas y disparidades en función del ámbito geográfico donde se ubica la tipología edificatoria y las soluciones constructivas que las constituyen. Así:

Trabajos similares realizados en España muestran que el consumo energético requerido para la fabricación de los materiales de construcción suponen aproximadamente 5.754 $\mathrm{MJ} / \mathrm{m}^{2}$, oscilando según la tipología, siendo los materiales de mayor impacto el acero, el cemento y la cerámica (1).

En Cataluña (21) los impactos ocasionados por los materiales de construcción suponen un total de $2.792,8 \mathrm{~kg} / \mathrm{m}^{2}$, siendo los granulares pétreos seguidos de los materiales cerámicos los que suponen un porcentaje mayor en la edificación y siendo nuevamente la estructura seguido de los cerramientos exteriores los subsistemas constructivos que consumen mayores recursos. La energía consumida por metro cuadrado en la fabricación de materiales asciende a casi $9.000 \mathrm{MJ}$, en el caso de una tipología de edificio residencial plurifamiliar.

En Valladolid (9), estudios realizados que comparan el impacto generado por viviendas unifamiliares de bajo impacto ambiental frente a las tipologías convencionales en esta provincia muestran un consumo de recursos materiales de $1.690,81 \mathrm{~kg} / \mathrm{m}^{2}$, siendo los subsistemas constructivos cimentación y movimientos de tierra los de require less resource consumption and hence lower energy consumption compared to the homes with horizontal development.

Regarding the materials used in construction, and taking into consideration that the structural characteristics of both models are similar (reinforced concrete structure, one-way slabs, ceramic brick siding, aluminum and flat roof) the percentages are also alike. However, the covers of single-family homes are mixed, as they have headframes in the tile roof. Consequently, the energy of this subsystem is higher than for residential blocks. On the other hand, the structure of single-family homes require a higher energy consumption, this is due to their type of foundation: blocks of reinforced concrete with small pillars and suspended floor, which would be directly related to the type of ground where it is founded.

In relation to the building subsystems, the differences in the foundation of those mentioned typologies (concrete headframes in terraced single-family houses and reinforced concrete slab in high-rise buildings), generates a considerable decrease in the first one.

We note that the results of similar studies performed with different sources of information and tools for life cycle analysis of materials, show similarities and differences depending on the geographical area where the building type and their construction solutions are located. For this reason:

Similar researches carried out in Spain illustrate that the energy consumption required for manufacturing building materials account for approximately $5754 \mathrm{MJ} / \mathrm{m}^{2}$, varying according to the type. The materials with greatest impact are steel, cement and ceramics (1).

In Catalonia (21) the impact caused by building materials are overall $2792.8 \mathrm{~kg} / \mathrm{m}^{2}$, with the granular stone followed by the ceramic materials as the ones with higher percentage. Regarding the subsystems, again the structure, followed by exterior walls, are the ones that consume more resources. The energy consumed per square meter in the manufacture of materials rise to almost $9000 \mathrm{MJ}$, in the case of a residential multifamily building type.

In Valladolid (9), studies that compare the impact generated by single-family homes with low environmental impact compared to conventional types in this province illustrate a consumption of material resources of $1690.81 \mathrm{~kg} / \mathrm{m}^{2}$. In this case, the foundation and building earth movements represent the subsystems 
mayor consumo. En este caso las viviendas cuentan con unos $175 \mathrm{~m}^{2}$, con sótano y cubierta inclinada, principales diferencias con la tipología de vivienda unifamiliar estudiada en este trabajo, consecuencia de la adaptación a la climatología del lugar. Los resultados comparados con nuestras tipologías nos muestran cómo el incluir una planta de sótano en las viviendas unifamiliares y el cambio de cubierta plana por el de inclinada, no hace aumentar el consumo de recursos por $\mathrm{m}^{2}$ construido, puesto que nuestros resultados rondan los $2.934 \mathrm{~kg} / \mathrm{m}^{2}$.

En Lanzarote (22), trabajos realizados con el programa holandés de análisis de ciclo de vida de materiales SIMAPRO4 y la base de datos BEDEC del ITeC muestran que el consumo de recursos materiales en edificios plurifamiliares suponen un total de $1.823,34 \mathrm{~kg} / \mathrm{m}^{2}$ y las viviendas unifamiliares de unos $115 \mathrm{~m}^{2}$ un total de 3.719,85 $\mathrm{kg} / \mathrm{m}^{2}$, siendo en ambos el subsistema constructivo correspondiente a la estructura el de mayor consumo de recursos con un $41,48 \%$ y un $33,88 \%$, respectivamente, siendo los áridos y los morteros los recursos materiales más consumido en ambas tipologías. En los mismos edificios la energía primaria en base a los recursos materiales consumidos supone un total de $5.470,58 \mathrm{MJ} / \mathrm{m}^{2}$ y $8.543,13 \mathrm{MJ} / \mathrm{m}^{2}$, respectivamente.

Recordemos que nuestra tipología de estudio viviendas unifamiliares consumen $10.461,02 \mathrm{MJ} / \mathrm{m}^{2}$ y las plurifamliares $8.843,90 \mathrm{MJ} / \mathrm{m}^{2}$, resultados muy superiores a los de Lanzarote, consecuencia de la sustitución de los ladrillos cerámicos, comúnmente usados en las tipologías constructivas de la península y en concreto de las estudiadas; por los bloques de mortero prefabricado, lo que sitúan a este componente en un lugar preferente y generalmente sustituyendo los impactos de la cerámica, minimizando a su vez el impacto global generado por esta tipología con respecto a las estudiadas, por cuanto los materiales cerámicos son unos de los de mayor consumo energético requeridos en su proceso de fabricación.

El trabajo en Lanzarote concluye que los impactos más importantes de los materiales se producen de una parte por los materiales de mayor peso en el edificio (cemento, morteros, cerámicas, áridos y aceros) y de otra por los metales especiales (aluminio, cobre...), mientras que en las tipologías estudiadas prevalece el hormigón, seguido de sus prefabricados y en tercer lugar el acero, estando en consecuencia relacionada con los hábitos constructivos del lugar donde se construye.

En definitiva, la metodología propuesta y la generalización del modelo obtenido, extensible a cualquier tipología edificatoria y ámbito geográfico, permite cuantificar el consumo energético total del sector construcción, obteniendo resultados comparables y en la misma línea que diferentes trabajos realizados en la misma área. with higher energy consumption. Here the houses have about $175 \mathrm{~m}^{2}$, with sloping roof and basement, major differences with the single-family housing type studied in this paper. This is consequence of the adaptation to the climate of each area. These results compared with our types show how the inclusion of a basement floor in houses and changing the flat roof to one bent do not increase the resources consumption per $\mathrm{m}^{2}$ built, since our results are around $2934 \mathrm{~kg} / \mathrm{m}^{2}$.

In Lanzarote (22), different studies undertaken with the Netherland program life cycle analysis of materials SIMAPRO4 and the BEDEC database of ITeC show that consumption of material resources in multi-familiar buildings involve $1823.34 \mathrm{~kg} / \mathrm{m}^{2}$. Regarding single-familiar housing of about $115 \mathrm{~m}^{2}$, the sum rises to $3719.85 \mathrm{~kg} / \mathrm{m}^{2}$. In both cases, the structure is the constructive subsystem with the highest consumption of resources, representing $41.48 \%$ and $33.88 \%$ and respectively. Furthermore, the grains and mortar materials are the resources consumed the most in both types of construction. In the same buildings, the primary energy resources based on the materials consumed represent an amount of $5470.58 \mathrm{MJ} / \mathrm{m}^{2}$ and $8543.13 \mathrm{MJ} / \mathrm{m}^{2}$, respectively.

It is worth to mention that our studied type of singlefamily houses consume $10461.02 \mathrm{MJ} / \mathrm{m}^{2}$ while the multi-family houses do $8843.90 \mathrm{MJ} / \mathrm{m}^{2}$, results much higher than Lanzarote's. This is a result of the replacement of ceramic bricks -commonly used in the constructions of the Spanish peninsula and in particular of those studied-, for precast mortar blocks. Consequently, this material is generally preferred and substitute the impacts caused by ceramics, minimizing in turn the overall impact generated by this type with respect to those studied, because the ceramic materials are among the ones which consumed the most energy during their manufacturing process.

The Lanzarote's research concludes that the most important impacts caused by the materials are produced, on one hand, by the ones heavier (concrete, mortar, ceramics, grains and steel) and other special metals (such as aluminium, copper, etc.). Conversely, in our studied types, the concrete precast, followed by the prefabricated concrete and the steel. Thus, the building habits depend on the area of construction.

Definitely, the proposed methodology and the generalization of the model obtained, applicable to any building type and geographical area, allow the quantification of the overall energy consumption in the construction sector. Moreover, it provides comparable results and it is in line with different studies conducted in the same milieu. 
Su contribución al conocimiento de los impactos ambientales, relacionados con el consumo energético en el sector de la construcción, redunda en la búsqueda de políticas medioambientales equilibradas, conducentes a la minimización y mejora del impacto ambiental ocasionado en nuestra sociedad, tendentes a conseguir una vida de los edificios más sostenible, ofreciéndose como un modelo de referencia sobre el que comparar las diferentes propuestas que se generen y su verificación, desde la óptica de los recursos materiales empleados en edificación, como medida de aproximación a una arquitectura medioambientalmente correcta.
In conclusion, this method contributes to the knowledge of the environmental impacts related to the energy consumption in the construction sector. It promotes the search for balanced environmental policies, able to lead to the minimization of the environmental impact caused in our society and aiming to get a more sustainable buildings' life. Hence, it represents a benchmark on which to compare and verify the different proposals that may be generated, from the standpoint of material resources used in construction, as a proxy to an environmentally appropriate architecture.

\section{BIBLIOGRAFÍA / BIBLIOGRAPHY}

(1) Zabalza Bribián, I.; Valero Capilla, A.; Aranda Usón, A.: "Life cycle assessment of building materials: Comparative análisis of energy and environmental impacts and evaluation of the eco-efficiency improvement potencial", Build. Environ., vol. 46 (2011), pp. 11331140. http://dx.doi.org/10.1016/j.buildenv.2010.12.002

(2) Wadel, G.: "La sostenibilidad en la construcción industrializada. La construcción modular ligera aplicada a la vivienda". Tesis doctoral. Universidad Politécnica de Cataluña, departamento de construcciones arquitectónicas, (2009). http://www.tdx.cat/TDX-0122110-180946.

(3) Mercader, Ma P.; Marrero, M.; Solís, J.; Montes, Ma. V.; Ramírez de Arellano, A.: "Cuantificación de los recursos materiales consumidos en la ejecución de la cimentación", Inf. Constr., vol. 62, no 517 (2010), pp. 125-132. doi: 10.3989/ic.09.000.

(4) Wadel, G.; Avellaneda, J.; Cuchí, B.: "La sostenibilidad en la arquitectura industrializada: cerrando el ciclo de los materiales". Inf. Constr., vol. 62, no 517 (2010), pp. 37-51. doi: 10.3989/ic.09.067. http://dx.doi.org/10.3989/ic.09.067

(5) Cuchí, A.; Wadel, G.; López, F.; Sagrera, A.: Guía de la eficiencia energética para administradores de fincas, p. 148, 1a edición Fundación Gas Natural, España (2007).

(6) Goldenberg, J.: Energía, medio ambiente \& desenvolvimiento. Sao Paulo. Edusp (1998).

(7) Webb, R.: "Building insulation for sustainability-guideline and standards". Proceedings of international conference sustainable building, Oslo, Norway (2002).

(8) Edwards, B.; Hyett, R.: Rough guide to sustainability. London: RIBA Enterprises (2001).

(9) González, Ma. J.; García Navarro, J.: "Assessment of the decrease of $\mathrm{CO}_{2}$ emissions in the construction field through the selection of materials: Practical case study of three houses of low environmental impact". Build. Environ., vol. 41 (2006), pp. 902-909. http://dx.doi.org/10.1016/j.buildenv.2005.04.006

(10) Khasreen, M.; Banfill, P.; Menzies, G.: "Life-cycle assessment and the environmental impact of buildings: a review". Sustainability, vol. 3 (2009), pp. 674-701. http://dx.doi.org/10.3390/su1030674

(11) Kellenberger, D.; Althaus, H-J.: "Relevance of simplificatios in LCA of building components", Build. Environ., vol. 44 (2009), pp. 818825. http://dx.doi.org/10.1016/j.buildenv.2008.06.002

(12) Mercader, Ma P.: "Cuantificación de los recursos consumidos y emisiones de CO2 producidas en las construcciones de Andalucía y sus implicaciones en el Protocolo de Kioto". Tesis doctoral. Universidad de Sevilla, vol. 1 (2010), pp. 119-123. http://fondosdigitales.us.es/tesis/

(13) ICARO/CTAV. 100 Materiales Sostenibles. Valencia: Colegio Territorial de Arquitectura de Valencia, (2003).

(14) Athena Institute, Canada. http://www.athenasmi.ca/about/IcaModel.html.

(15) BEDEC PR/PCT. http://www.itec.cat.

(16) Malin, N.: "Life cycle assessment for whole buildings:seeking the holy grail". Building Design and Construction, November (2005), pp. 6-11.

(17) Manual de Costes de la Construcción, PRESTO V.8.6, p.233, Soft S.A., Madrid, España (1999).

(18) Base de Costes de la Construcción de Andalucía 2010. Consejería de Vivienda y Ordenación del Territorio. Junta Andalucía (2010). http://www.juntadeandalucia.es/viviendayordenaciondelterritorio/www/jsp/estatica.jsp?pma=0\&ct=-1\&pmsa=0\&e=biblioteca_archivos/../planificacion/publicaciones/banco_precios_construccion/bcca08/bcca08.html.

(19) Ramírez de Arellano, A.: La Teoría de sistemas al Servicio del análisis de Presupuesto de Obra, Colegio Oficial de Aparejadores y Arquitectos Técnicos de Sevilla (1989), p. 456.

(20) Pardo Merino, A.; Ruiz Díaz, M. A.: SPSS 11. Guía para el análisis de datos, Mc. Graw Hill, Madrid (2002), p. 715.

(21) Cuchí Burgos, A.: Arquitectura i sostenibilitat, Universidad Politécnica de Cataluña, Barcelona (2005), p. 81.

(22) Álvarez-Ude, L.; Casanovas, X.; Cuchí, A.; Baldrich, X.: Análisis de los materiales empleados en la edificación en la isla de Lanzarote desde una perspectiva medioambiental, Caja Insular de Ahorros de Canarias. Equipo Life 2001-2004. Cabildo de Lanzarote (2004), p. 113. 